\title{
Wideband Diaphragm Polarizer for Satellite Antennas
}

\begin{abstract}
This article presents the design and characteristics of new broadband polarizer based on a square guide with diaphragms. Matching and polarization characteristics of the guide polarizer have been simulated and optimized. Frequency dependences of the simulated characteristics are presented. Developed square guide polarizer can be applied in modern satellite antennas.
\end{abstract}

Keywords: microwave engineering, telecommunication systems, guide polarizer, antenna engineering, polarization, electromagnetic simulation, satellite telecommunication systems.

\section{INTRODUCTION}

Nowadays, new extended frequency bands are widely applied in modern satellite information systems, terrestrial communications and radio astronomy [1-19]. In this regard the development and simulation of new designs of waveguide iris polarizers is a relevant problem [20-32]. Iris polarizers are an essential part of the feeds of satellite reflector antennas. The application of iris polarizers allows to operate at two orthogonal circular polarizations. Consequently, the volumes of transmitted information in the telecommunication system increase in two times.

\section{DESIGN OF THE DEVELOPED IRIS POLARIZER}

A waveguide iris polarizer is a microwave device, which performs the conversion of the electromagnetic waves with orthogonal circular polarizations into electromagnetic waves with linear polarizations. This operation is performed by the introduction of an additional differential phase shift of $90^{\circ}$ between the modes of a waveguide with orthogonal polarizations.

Typically, iris polarizers and orthomode transducers are based on circular and coaxial waveguides [3339], and square waveguides [40-55]. The main advantage of the iris polarizer is its most wideband operation compared to other designs. Besides, it provides efficient electromagnetic characteristics and good matching of a structure. The main disadvantage is the increase of the iris polarizer's length for the wide and ultra wide operating bands. Iris polarizers based on guides with irises are technological devices and they are easily fabricated by milling.

Inner structure of typical structure of the waveguide iris polarizer is shown in Fig. 1. The iris polarizer is based on the square waveguide and several diaphragms.

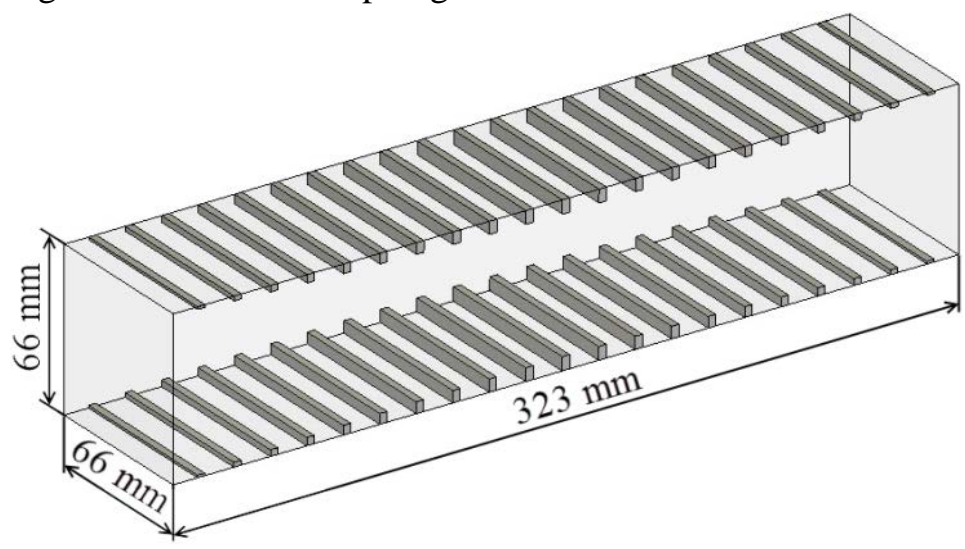

Fig. 1. The structure of a iris polarizer based on the square waveguide with irises

\section{ELECTROMAGNETIC CHARACTERISTICS OF DEVICE}

The sizes of the waveguide and irises were varied for the optimization. The most important parameter of a iris polarizer is differential phase shift. Optimized differential phase shift of the iris polarizer is demonstrated in Fig. 2. The introduced differential phase shift is $90^{\circ} \pm 3^{\circ}$ in the operating satellite band 3.4$4.8 \mathrm{GHz}$. The crosspolar isolation of the iris polarizer is higher than $31 \mathrm{~dB}$. Fig. 3 presents the frequency dependences of VSWR. The solid curve corresponds to the vertical polarization. The dashed curve corresponds to the horizontal polarization. As one can see, VSWR is less than 1.1 for both polarizations of waveguide modes. 


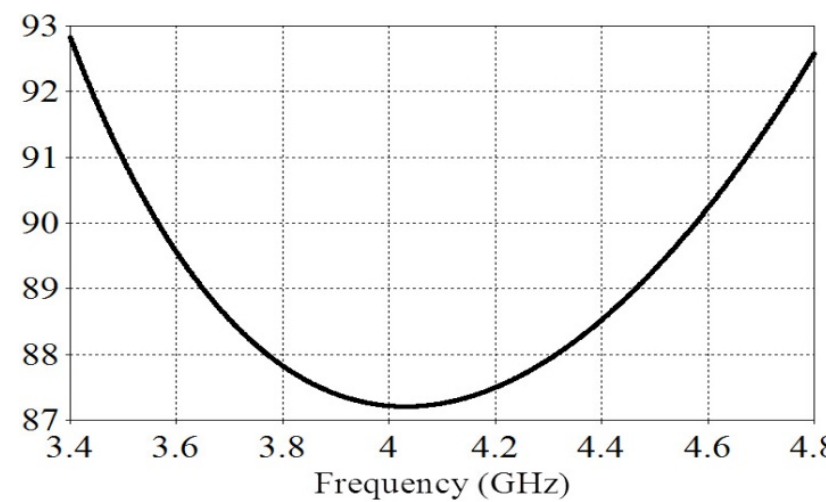

Fig. 2. Differential phase shift of a iris polarizer in the extended satellite C-band

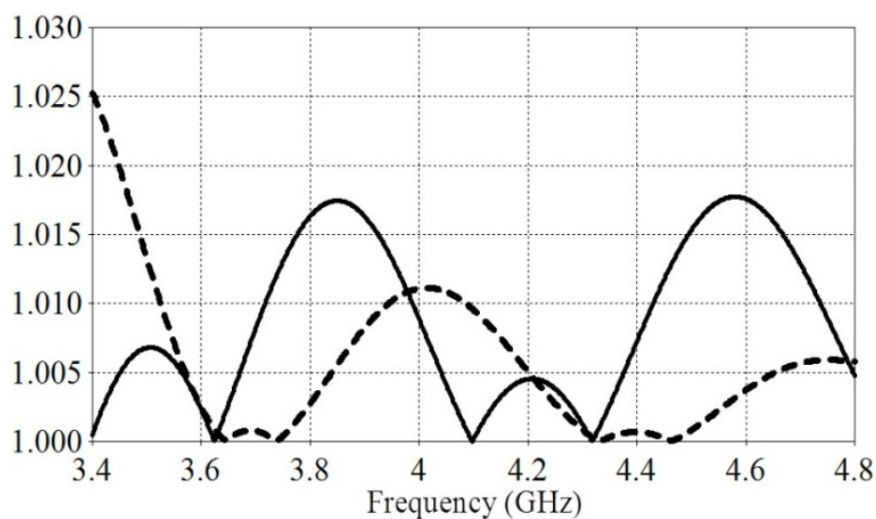

Fig. 3. VSWRs of a iris polarizer in the extended satellite C-band for both polarizations

\section{CONCLUSIONS}

Consequently, a new iris polarizer has been developed and optimized in the article. The structure consists of a square waveguide with metal irises in it. Developed iris polarizer provides efficient phase characteristic and good matching with low VSWR level. Developed iris polarizer can be widely applied in modern satellite antenna systems.

\section{REFERENCES}

1. Piltyay S., Bulashenko A., Kushnir H., Bulashenko O. Information resources economy in satellite systems based on new microwave polarizers with tunable posts // Path of Science. 2020. Vol. 6, № 11. P. 5001-5010. DOI: 10.22178/pos.55-1.

2. Piltyay S. I. High performance extended C-band 3.4-4.8 GHz dual circular polarization feed system // XI International Conference on Antenna Theory and Techniques (ICATT), Kyiv, Ukraine, May 2017, pp. $284-287$. DOI: 10.1109/ICATT.2017.7972644.

3. Piltyay S., Bulashenko A., Demchenko I. Wireless sensor network connectivity in heterogeneous 5G mobile systems // IEEE International Conference on Problems of Infocommunications. Science and Technology (PIC S\&T), Kharkiv, Ukraine, October 2020, pp. 508-513.

4. Bulashenko A., Piltyay S., Demchenko I. Energy efficiency of the D2D direct connection system in 5G networks // IEEE International Conference on Problems of Infocommunications. Science and Technology (PIC S\&T), Kharkiv, Ukraine, October 2020, pp. 324-329.

5. Bulashenko A., Piltyay S., Polishchuk A., Bulashenko O. New traffic model of M2M Technology in 5G wireless sensor networks // IEEE 2nd International Conference on Advanced Trends in Information Theory (IEEE ATIT), Kyiv, Ukraine, November 2020, pp. 125-131. DOI: 10.1109/ATIT50783.2020.9349305.

6. Bulashenko A. Evaluation of D2D Communications in 5G networks // Visnik NTUU KPI SeriiaRadiotekhnika, Radioaparatobuduvannia. 2020. Vol. 81. P. 21-29. DOI: 10.20535/RADAP.2020.81.21-29.

7. Piltyay S., Bulashenko A., Sushko O., Bulashenko O., Demchenko I. Analytical modeling and optimization of new Ku-band tunable square waveguide iris-post polarizer. International Journal of Numerical Modelling: Electronic Networks, Devices and Fields. 2021. Vol. 34, № 4. P. 1-27. DOI: 10.1002/JNM.2890.

8. Piltyay S., Bulashenko A., Demchenko I. Compact polarizers for satellite information systems // IEEE International Conference on Problems of Infocommunications. Science and Technology (PIC S\&T 2020), Kharkiv, Ukraine, October 2020, pp. 350-355.

9. Piltyay S.I., Bulashenko A.V., et al. Analytical synthesis of waveguide iris polarizers // Telecommunications and Radio Engineering. 2020. Vol. 79, № 18. P. 1579-1597. DOI: 10.1615/TelecomRadEng.v79.i18.10.

10. Bulashenko A. V., Piltyay S. I., Demchenko I. V. Wave matrix technique for waveguide iris polarizers simulation. Theory // Journal of Nano- and Electronic Physics. 2020. Vol. 12, № 6. P. 06026-1-06026-5. DOI: 10.21272/jnep.12(6).06026.

11. Bulashenko A. V., Piltyay S. I., Demchenko I. V. Wave matrix technique for waveguide iris polarizers simulation. Numerical results // Journal of Nano- and Electronic Physics. 2020. Vol. 13, № 3. - P. 03023-1-03023-5. DOI: DOI: 10.21272/jnep.13(3).03023.

12. Bulashenko A. V., Piltyay S. I. Equivalent microwave circuit technique for waveguide iris polarizers development // Visnyk NTUU KPI Seriia - Radiotekhnika, Radioaparatobuduvannia. 2020. Vol. 83. P. 17-28. DOI: 10.20535/RADAP.2020.83.17-28. 
13. Bulashenko A., Piltyay S., Demchenko I. Analytical technique for iris polarizers development // IEEE International Conference on Problems of Infocommunications. Science and Technology (PIC S\&T 2020), Kharkiv, Ukraine, October 2020, pp. 464-469.

14. Piltyay S., Bulashenko A., Herhil Y., Bulashenko O. FDTD and FEM simulation of microwave waveguide polarizers // IEEE 2nd International Conference on Advanced Trends in Information Theory (IEEE ATIT), Kyiv, Ukraine, November 2020, pp. 357-363. DOI: 10.1109/ATIT50783.2020.9349339.

15. Bulashenko A., Piltyay S., Kalinichenko Ye., Bulashenko O. Mathematical modeling of iris-post sections for waveguide filters, phase shifters and polarizers // IEEE 2nd International Conference on Advanced Trends in Information Theory, Kyiv, Ukraine, November 2020, pp. 330-336. DOI: 10.1109/ATIT50783.2020.9349321.

16. Piltyay S.I., Bulashenko A.V., Herhil Y.Y. Numerical performance of FEM and FDTD methods for the simulation of waveguide polarizers // Visnyk NTUU KPI Seriia - Radiotekhnika, Radioaparatobuduvannia. 2021. Vol. 84. P. 11-21. DOI: 10.20535/RADAP.2021.84.11-21.

17. Piltyay S.I., Bulashenko A.V. Microwave waveguide polarizers optimization in frequency and time domains // Prospects and priorities of research in science and technology: collective monograph / Baltija Publishing. - 2021. P. 179-198. DOI: 10.30525/978-9934-26-008-7.2-10.

18. Bulashenko A., Piltyay S. Modelling and optimization of waveguide polarizers with the account of irises thickness // Integration of traditional and innovation processes of development of modern science: collective monograph / Baltija Publishing. - 2021. P. 109-140. DOI: 10.30525/978-9934-26-021-6-34.

19. Piltyay S. I. Enhanced C-band coaxial orthomode transducer // Visnyk NTUU KPI Seriia - Radiotekhnika, Radioaparatobuduvannia. 2014. Vol. 58. P. 27-34. DOI: 10.20535/RADAP.2014.58.27-34.

20. Piltyay S. I., Bulashenko A. V., Demchenko I. V. Waveguide iris polarizers for Ku-band satellite antenna feeds // Journal of Nano- and Electronic Physics. 2020. Vol. 12, № 5. P. 05024-1-05024-5. DOI: 10.21272/jnep.12(5).05024.

21. Piltyay S.I., Sushko O.Yu., Bulashenko A.V., Demchenko I.V. Compact Ku-band iris polarizers for satellite telecommunication systems // Telecommunications and Radio Engineering. 2020. Vol. 79, № 19. P. 1673-1690. DOI: 10.1615/TelecomRadEng.v79.i19.10.

22. Piltyay S. Numerically effective basis functions in integral equation technique for sectoral coaxial ridged waveguides // Proceedings of 14-th International Conference on Mathematical Methods in Electromagnetic Theory (MMET 2012), Kyiv, Ukraine, August 2012, pp. 492-495. DOI: 10.1109/MMET.2012.6331195.

23. Piltyay S., Bulashenko A., Kushnir H., Bulashenko O. New tunable iris-post square waveguide polarizers for satellite information systems // IEEE 2nd International Conference on Advanced Trends in Information Theory (IEEE ATIT 2020), Kyiv, Ukraine, November 2020, pp. 342-348. DOI: 10.1109/ATIT50783.2020.9349321.

24. Bulashenko A.V., Piltyay S.I., et al. Tunable square waveguide polarizer with irises and posts // Technical Engineering. 2020. Vol. 86, № 2. P. 108-116. DOI: 10.26642/ten-2020-2(86)-108-116.

25. Bulashenko A.V., Piltyay S.I., et al. Compact waveguide polarizer with three antiphase posts // Visnyk VPI. 2020. Vol. 5. P. 97-104. DOI: 10.31649/1997-9266-2020-151-5-97-104.

26. Bulashenko A.V., Piltyay S.I., et al. Optimization of a polarizer based on a square waveguide with irises // Science-Based Technologies. 2020. Vol. 47, № 3. P. 287-297. DOI: 10.18372/2310-5461.47.14878.

27. Bulashenko A.V., Piltyay S.I., et al. Waveguide polarizer with three irises for antennas of satellite television systems // Science-Based Technologies. 2021. Vol. 49, № 1. P. 39-48. DOI: 10.18372/2310-5461.49.15290.

28. Piltyay S. I., et al. High performance waveguide polarizer for satellite information systems // Bulletin of Cherkasy State Technological University. 2020. Vol. 4. P. 14-26. DOI: 10.24025/2306-4412.4.2020.217129.

29. Bulashenko A.V., Piltyay S.I., Demchenko I.V. Simulation of compact polarizers for satellite telecommunication systems with the account of thickness of irises // KPI Science News. 2021. Vol. 1. P. 7-15.

30. Piltyay S.I. Wideband antiphase power combiner/divider // 9-th International Youth Science \& Engineering Conference «Modern Problems of Radio Engineering and Telecommunications», Sevastopol, Ukraine, 2013 , p. 220.

31. Piltyay S. Enhanced C-band antiphase power combiner/divider // The 2-nd International Conference “Radioengineering fields, signals, equipment and systems”, Kyiv, Ukraine, 2013, pp. 105-106.

32. Piltyay S., Bulashenko A. Microwave waveguide polarizers optimization in frequency and time domains // Boston, USA, Theoretical aspects of modern engineering: collective monograph / International Science Group. - 2020. P. 251-254. DOI: 10.46299/ISG.2020.MONO.TECH.III.

33. Piltyay S. Information resources economy in satellite systems based on new microwave polarizers with tunable posts / S. Piltyay, et al. // Path of Science. - 2020. - Vol. 6, No 11. - pp. 5001-5010.

34. Bulashenko A.V. Compact waveguide polarizer with three antiphase posts / A.V. Bulashenko, et al. // Visnyk VPI. - 2020. - Vol. 5. - pp. 97-104. [In Ukrainian]. DOI: 10.31649/1997-9266-2020-151-5-97-104.

35. Bulashenko A.V. Tunable square waveguide polarizer with irises and posts / A.V. Bulashenko, et al. // Technical Engineering. - 2020. - Vol. 86, no 2. - pp. 108-116. DOI: 10.26642/ten-2020-2(86)-108-116. 
36. Bulashenko A.V. Optimization of a polarizer based on a square waveguide with irises / A.V. Bulashenko, et al. // Science-Based Technologies. - 2020. - Vol. 47, No. 3. - pp. 287-297. (in Ukrainian).

37. Bulashenko A.V. Waveguide polarizer with three irises for antennas of satellite television systems / A.V. Bulashenko, et al. // Science-Based Technologies. - 2021. - Vol. 49, No. 1. - pp. 39-48.

38. Piltyay S.I. Waveguide iris polarizers for Ku-band satellite antenna feeds / S.I. Piltyay, et al. // Journal of Nano- and Electronic Physics. - 2020. - Vol. 12, No. $5 . \quad$ pp. 05024-1-05024-5. http://doi.org/10.21272/jnep.12(5).05024.

39. Piltyay S.I. High performance waveguide polarizer for satellite information systems / S.I. Piltyay, et al. // Bulletin of Cherkasy State Technological University. - 2020. - Vol. 4. - pp. 14-26. [In Ukrainian]. DOI: 10.24025/2306-4412.4.2020.217129.

40. Piltyay S. New tunable iris-post square waveguide polarizers for satellite information systems / S. Piltyay, et al. // IEEE 2nd International Conference on Advanced Trends in Information Theory, 25-27 November 2020, Kyiv, Ukraine, pp. 342-348. DOI: 10.1109/ATIT50783.2020.9349357.

41. Bulashenko A. Mathematical modeling of iris-post sections for waveguide filters, phase shifters and polarizers / A. Bulashenko, et al. // IEEE 2nd International Conference on Advanced Trends in Information Theory, 25-27 November 2020, Kyiv, Ukraine, pp. 330-336. DOI: 10.1109/ATIT50783.2020.9349321.

42. Piltyay S. Analytical modeling and optimization of new Ku-band tunable square waveguide iris-post polarizer / S.I. Piltyay, et al. // International Journal of Numerical Modelling: Electronic Networks, Devices and Fields. - 2021. Vol. 34, no. 4. - pp. 1-27. DOI: 10.1002/JNM.2890.

43. Bulashenko A.V. Equivalent microwave circuit technique for waveguide iris polarizers development / A.V. Bulashenko, S.I. Piltyay // Visnyk NTUU KPI Seriia - Radiotekhnika, Radioaparatobuduvannia. - 2020. - Vol. 83. pp. 17-28. http://doi.org/10.20535/RADAP.2020.83.17-28.

44. Bulashenko A.V. Wave matrix technique for waveguide iris polarizers simulation. Theory / A.V. Bulashenko, et al. // Journal of Nano- and Electronic Physics. - 2020. - Vol. 12, no. 6. - pp. 06026-1-06026-5. DOI: 10.21272/jnep.12(6).06026.

45. Bulashenko A. Analytical technique for iris polarizers development / A. Bulashenko, et al. // IEEE International Conference on Problems of Infocommunications. Science and Technology. - Kharkiv, Ukraine, 2020. pp. 471-476.

46. Piltyay S.I. Analytical synthesis of waveguide iris polarizers / S.I. Piltyay, et al. // Telecommunications and Radio Engineering. - 2020. - Vol. 79, No 18. - pp. 1579-1597.

47. Bulashenko A.V. Simulation of compact polarizers for satellite telecommunication systems with the account of thickness of irises / A.V. Bulashenko, S.I. Piltyay, I.V. Demchenko // KPI Science news. - 2021. - Vol. 1. - pp. 7-15.

48. Piltyay S.I. Compact Ku-band iris polarizers for satellite telecommunication systems / S.I. Piltyay, et al. // Telecommunications and Radio Engineering. - 2020. - Vol. 79, no. 19. - pp. 1673-1690. DOI:10.1615/TelecomRadEng.v79.i19.10.

49. Bulashenko A. New traffic model of M2M Technology in 5G wireless sensor networks / A. Bulashenko, et al. // IEEE 2nd International Conference on Advanced Trends in Information Theory, 25-27 November 2020, Kyiv, Ukraine, pp. 125-131.

50. Piltyay S.I. Wireless sensor network connectivity in heterogeneous 5G mobile systems / S.I. Piltyay, et al. // IEEE International Conference on Problems of Infocommunications. Science and Technology, Oct. 2020, Kharkiv, Ukraine, pp. 508-513.

51. Bulashenko A.V. Energy efficiency of the D2D direct connection system in 5G networks / A.V. Bulashenko, et al. // IEEE International Conference on Problems of Infocommunications. Science and Technology, Oct. 2020, Kharkiv, Ukraine, pp. 324-329.

52. Bulashenko A.V. Evaluation of D2D Communications in 5G networks / A.V. Bulashenko // Visnyk NTUU KPI Seriia - Radiotekhnika, Radioaparatobuduvannia. - 2020. - Vol. 81. - pp. 21-29. (in Ukrainian).

53. Bulashenko A.V. Combined criterion for the choice of routing based on D2D technology / A.V. Bulashenko // Radio Electronics, Computer Science, Control. - 2021. - Vol. 1. - pp. 7-13. (in Ukrainian).

54. Bulashenko A.V. Data upload system using D2D technology in the unlicensed frequency range as part of the 5G communication system / A.V. Bulashenko // Technical Engineering. - 2020. - Vol. 86, No. 2. - pp. 103-107. (in Ukrainian).

55. Bulashenko A.V. Resource allocation for low-power devices of M2M technology in 5G networks / A.V. Bulashenko // KPI Science news. - 2020. - Vol. 3. - pp. 7-13. (In Ukrainian). 